\title{
An unusual chiasmal visual defect in a patient with neuromyelitis optica: case report
}

\author{
Comprometimentoquiasmático incomum em um pacientecom neuromieliteóptica: \\ relatodecaso
}

\author{
Roberta Martins da Silva Costa ${ }^{1}$ \\ Antonio Carlos Santos ${ }^{2}$ \\ Laudo Silva Costa ${ }^{3}$
}

Trabalho realizado no Hospital das Clínicas da Faculdade de Medicina da Universidade de São Paulo - USP Ribeirão Preto (SP) - Brasil.

${ }^{1}$ Médica do Departamento de Oftalmologia e Mestre em Medicina pela Universidade de São Paulo - USP - Ribeirão Preto (SP) - Brasil.

${ }^{2}$ Professor do Departamento de Clínica Médica, Centro de Ciências das Imagens e Física Médica da Faculdade de Medicina da USP - Ribeirão Preto (SP) - Brasil.

${ }^{3}$ Professor Associado do Departamento de Oftalmologia da Faculdade de Medicina da USP - Ribeirão Preto (SP) - Brasil

Endereço para correspondência: Roberta Martins da Silva Costa. Hospital das Clínicas de Ribeirão Preto E-mail: rmscosta@hcrp.fmrp.usp.br

Recebido para publicação em 04.04.2005

Última versão recebida em 16.03.2006 Aprovação em 18.05.2006

Nota Editorial: Depois de concluída a análise do artigo sob sigilo editorial e com a anuência do Dr. Mário Luiz Ribeiro Monteiro sobre a divulgação de seu nome como revisor, agradecemos sua participação neste processo.

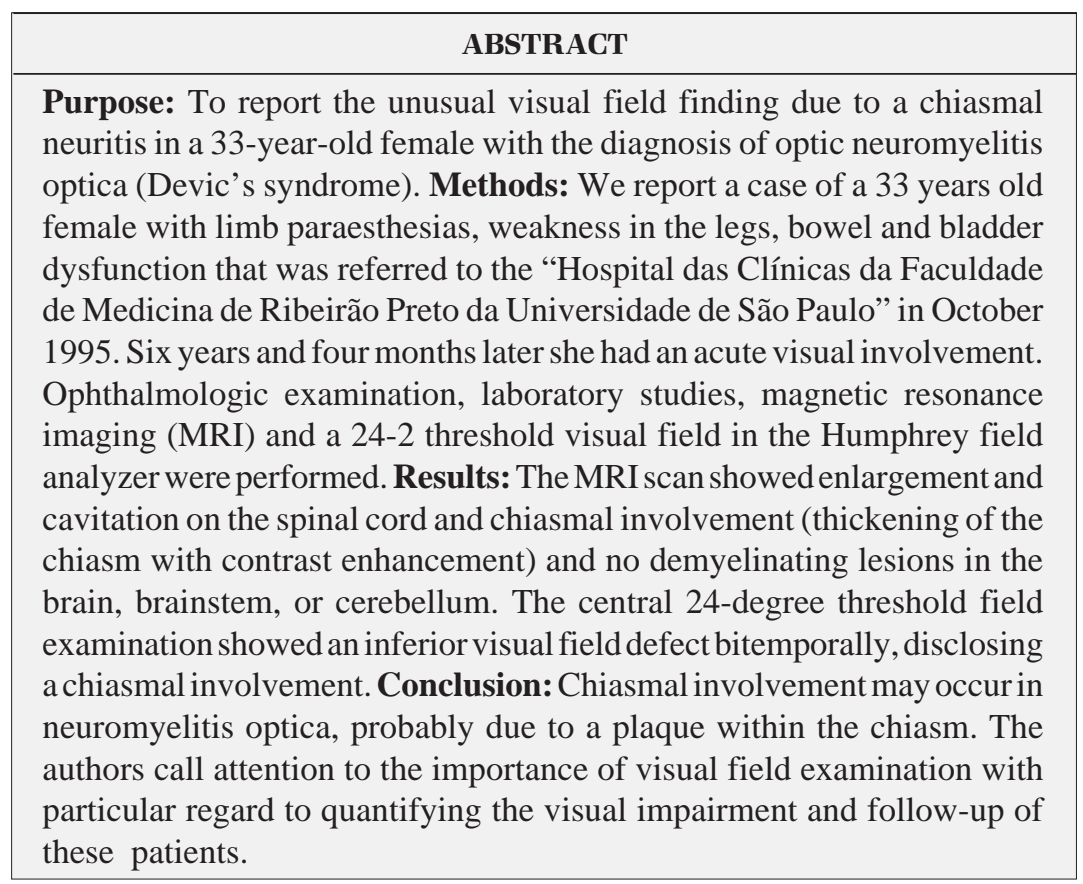

Keywords: Hemianopsia; Neuromyelitis optica/diagnosis; Optic chiasm; Scotoma; Perimetry; Optic neuritis

\section{INTRODUCTION}

The diagnosis of chiasmal syndrome can be divided into compressive and non-compressive lesions. Compressive lesions are a consequence of space occupying processes, usually from a pituitary adenoma with suprasellar extension (the most commom cause), a craniopharyngioma, a meningioma or an aneurysm ${ }^{(1-3)}$. Studies of the frequency distribution of scotoma patterns in patients with perichiasmal affections showed that the majority of scotomas was attributable to an involvement of the temporal hemifield in both eyes. The second most commom visual fields defect was anterior junction syndrome, characterized by advanced central scotoma in one eye and contralateral superior temporal field defect. Although bitemporal scotoma are very commom in chiasmal syndromes, the involvement of the lower quadrants were seen in only $0.3 \%$ of patients with compressive diseases and $1 \%$ of patients with chiasmal syndrome caused by diverse disesases ${ }^{(4)}$.

Chiasmal optic neuritis is a relative rare condition involving the optic chiasma, with a clinical appearance similar to that of retrobulbar neuritis. Patients usually present with uni or bilateral visual symptoms and a initial 
normal fundoscopy ${ }^{(5)}$. Many patients that had an episode of optic neuritis may develop demyelinating diseases, most frequently multiple sclerosis (MS). The syndrome known by Devic's name is characterized by a severe acute transverse myelitis accompanied by an acute, unilateral or bilateral optic neuropathy (neuromyelitis optica - NMO). It is a variant of demyelinative disease and its status as a distinct entity has been uncertain for many years ${ }^{(3,6-9)}$. In recent years, more detailed clinical features of NMO have been reported, allowing a better definition of the disease and its differentiation from $\mathrm{MS}^{(10)}$. We report a case of a patient with Devic's disease that developed an uncommon chiasmal visual field defect (bitemporal inferior scotoma).

\section{CASE REPORT}

A 33-years-old white woman presented in October 1995 with limb paraesthesia, weakness in the legs and with bowel and bladder dysfunction of six-week duration. The cerebrospinal fluid (CSF) was clear with normal pressure $\left(12 \mathrm{mmH}_{2} \mathrm{O}\right)$ and contained 28 cells $/ \mathrm{mm}^{3}$ (normal $<5$ cells $/ \mathrm{mm}^{3}$ ), $14 \mathrm{mg} / \mathrm{dL}$ total protein (normal $15-45 \mathrm{mg} / \mathrm{dL}$ ) and $63 \mathrm{mg} / \mathrm{dL}$ glucose (normal 40-80 mg/dL). No oligoclonal bands were detected. Complete blood count, chemistry profile, erythrocyte sedimentation rate, and an extensive investigation for autoimmune or inflammatory diseases were unrevealing. Magnetic resonance imaging (MRI) showed abnormal hyperintensity in spinal cord that extended from $\mathrm{C} 4$ to $\mathrm{C} 6$. The brain was normal, without periventricular lesions. It was concluded that she had a transverse myelitis. She was treated with intravenous pulse of methylprednisolone sodium succinate, 1 gram daily for 3 days followed by improvement of the spinal signs.

In February 2002 she presented bilateral visual loss. Her visual acuity was R.E.: 20/60 with -3.25 D sph and L.E.: 20/60 with $-3.50 \mathrm{D}$ sph. The examination revealed no abnormalities in eye movements. The pupils were isocoric and normally reactive to light. No relative afferent papillary defect was found. The optic disc and the retina were normal bilaterally. A central 24-2 threshold visual field test (SITA standard) performed with the Humphrey Field Analyzer II demonstrated lower bitemporal defects up to the point of fixation, a chiasmal type of visual field defect (Figure 1). MRI of the brain showed contrast enhancement of the optic chiasm (Figure 2) and it was concluded that she had a chiasmal demyelination. The findings were felt consistent with the diagnosis of neuromyelitis optica and she was treated with intravenous pulse of methylprednisolone 1.2 gram daily for 3 days followed by oral prednisone, $60 \mathrm{mg}$ /day for 10 days. After one month of followup the visual acuity and the visual fields returned to normal.

\section{DISCUSSION}

In this case we were in face of a 33-year-old woman with an acute onset of bilateral blurred vision and a bitemporal visual

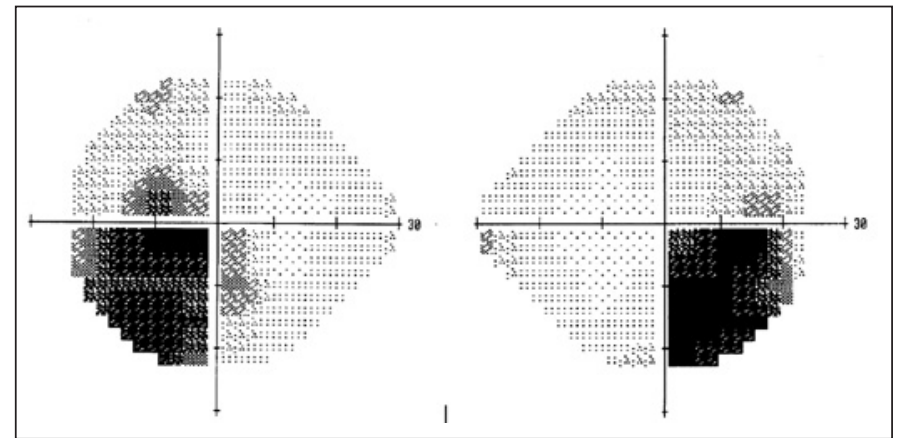

Figure 1 - Lower bitemporal defects demonstrated on visual field examination

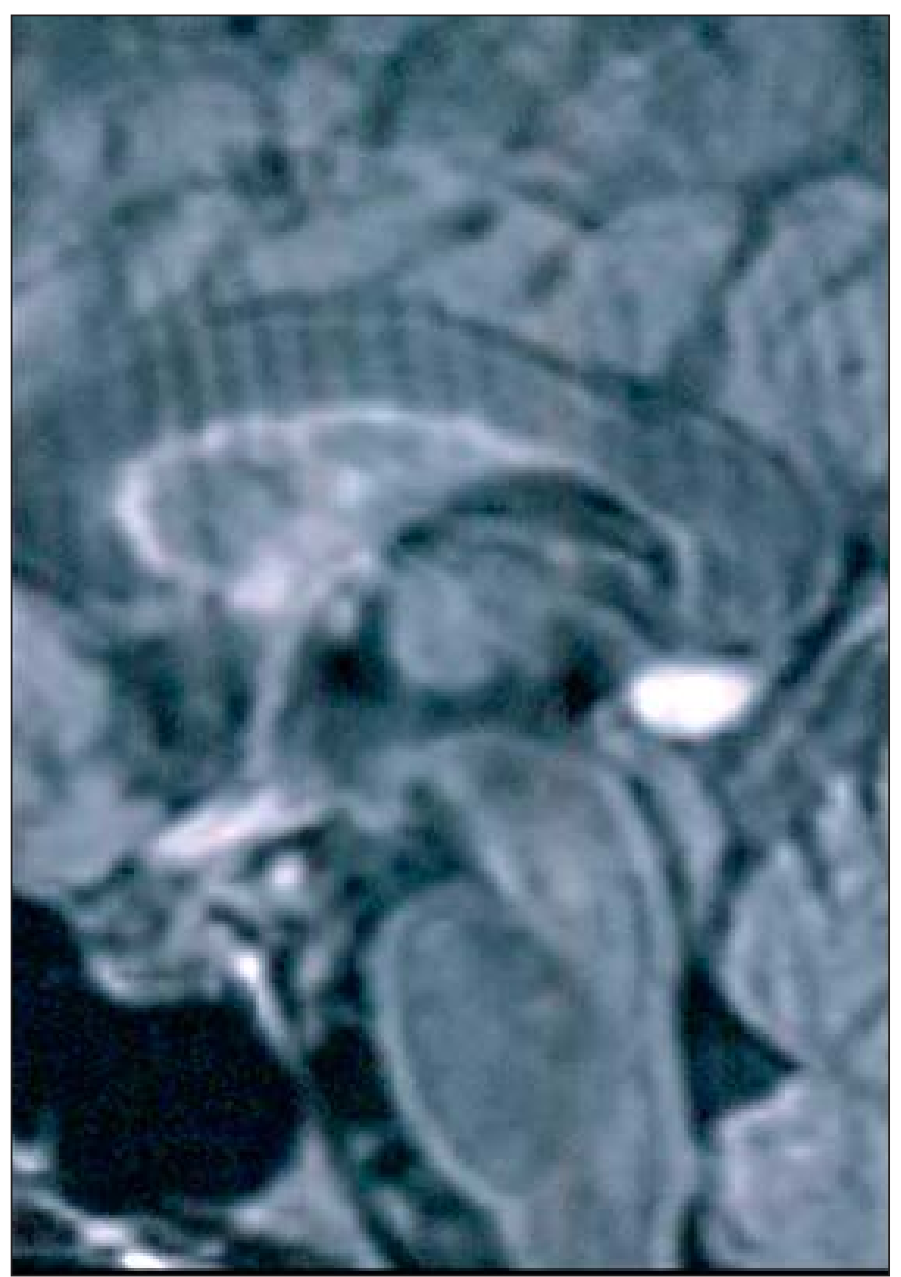

Figure 2 - MRI of the brain showing contrast enhancement of the chiasm

field defect. The hemianopia was bitemporal inferior incomplete, suggesting a lesion affecting the superior decussating fibers of the body of the chiasm with functional interference occurring in the superoposterior portion of the chiasm $^{(11)}$. This pattern of scotoma is not common in compressive diseases, in which injury usually comes from below (sella turcica, carotida), but may appear in intrinsic lesions of the chiasm 
that include demyelinating disease, sarcoidosis, meningitis, systemic lupus erythematosus, or a nerve tumor.

While compressive lesions are typified by a pattern of relentless and slow depression of monocular or binocular function, intrinsic lesions of the chiasm are usually acute in onset, often with bilateral blurred vision. Intrinsic lesions of the chiasm in demyelinative disease occurred in $5.1 \%$ of the cases in a study on 448 patients with acute optic neuritis who entered the Optic Neuritis Treatment Trial (ONTT) ${ }^{(12)}$.

Our patient was found to have Devic's neuromyelitis optica, a neurological condition characterized by a severe involvement of the optic nerves and spinal cord in a mono- or multiphasic manner. The diagnosis of NMO is very difficult at onset, since it is not distinguishable from acute disseminated encephalomyelitis or MS. Recent pathologic, cerebrospinal fluid (CSF) and conventional MRI studies have shown abnormalities which might help in differentiating patients with NMO from those with other demyelinating diseases. The diagnosis of NMO can be applied to patients satisfying all three absolute criteria (occurrence of optic neuritis, occurrence of acute myelitis, no evidence of clinical CNS involvement apart from the optic nerve and spinal cord) and one major supportive criterion (negative brain MRI at onset, spinal cord MRI with signal abnormality extending over three vertebral segments, CSF pleocytosis of $>50 \mathrm{WBC} / \mathrm{mm}^{3}$ ) or two minor supportive criteria (bilateral ON, severe $\mathrm{ON}$, severe myelitis) ${ }^{(10)}$. In our report, MRI revealed chiasmal defect associated with spinal cord signal abnormalities extending from $\mathrm{C} 4$ to $\mathrm{C} 6$. The patient showed no evidence of clinical or radiological CNS involvement and the CSF analysis revealed a pleocytosis. These findings were compatible with the diagnosis of NMO and the recovery of visual symptoms point to a multiphasic form. Patients with this form of disease experience less impairment from attacks than monophasic patients, but their long-term outcome is usually worse ${ }^{(13)}$.

A commonly encountered characteristic of optic chiasmal neuritis is the generally favorable prognosis, although some patients may have a prolonged course of visual loss over several months ${ }^{(14)}$. In NMO, early diagnosis will be critical if effective long-term treatment to prevent attacks becomes available because many patients develop severe, irreversible impairment early in the disease. Although MRI is helpful in revealing the site and nature of a disease affecting the visual pathway, it is only roughly able to predict visual disturbance in chiasmal involvement without providing any evidence of scotoma location and extent. This further underlines the importance of visual field examination with particular regard to quantifying the visual impairment and follow-up of these patients.

\section{RESUMO}

Objetivo: Relatar o caso de uma mulher de 33 anos de idade, com o diagnóstico de neuromielite óptica (síndrome de Devic) acometendo o quiasma óptico que apresentou um escotoma incomum no exame de campo visual. Métodos: Uma paciente do sexo feminino, portadora de parestesias nos membros inferiores, fraqueza nas pernas, disfunção da defecação e disfunção urinária, foi encaminhada para o Hospital das Clínicas da Faculdade de Medicina de Ribeirão Preto da Universidade de São Paulo em outubro do ano de 1995. Seis anos e quatro meses mais tarde ela sofreu acometimento visual agudo. Foram realizados exame oftalmológico completo, exame de líquor, ressonância nuclear magnética e um exame de campo visual no perímetro de Humphrey. Resultados: A ressonância magnética revelou espessamento e imagens de cavitações na medula espinal, assim como espessamento do quiasma óptico, acompanhado de aumento na captação do contraste. Não apareceu imagem sugestiva de processo desmielinizante no cérebro, tronco cerebral ou cerebelo. O exame 24-2 (campo visual central) demonstrou defeito bitemporal inferior, revelando assim o comprometimento do chiasma. Conclusão: Comprometimento do quiasma óptico pode ocorrer nos casos de neuromielite óptica, provavelmente devido a uma placa de desmielinização ocorrendo no quiasma. Os autores enfatizam a importância do exame de campo visual para quantificar o comprometimento das vias ópticas e acompanhar a evolução destes pacientes.

Descritores: Hemianopsia; Neuromielite óptica/diagnóstico; Quiasma óptico; Escotoma; Perimetria; Neurite óptica

\section{REFERENCES}

1. Mejico LJ, Miller NR, Dong LM. Clinical features associated with lesions other than pituitary adenoma in patients with an optic chiasmal syndrome. Am J Ophthalmol. 2004;137(5):908-13.

2. Foroozan R. Chiasmal syndromes. Curr Opin Ophthalmol. 2003;14(6):32531. Review.

3. Sacks JG, Melen O. Bitemporal visual field defects in presumed multiple sclerosis. JAMA. 1975;234(1):69-72.

4. Schiefer U, Isbert M, Mikolaschek E, Mildenberger I, Krapp E, Schiller J, et al. Distribution of scotoma pattern related to chiasmal lesions with special reference to anterior junction syndrome. Graefes Arch Clin Exp Ophthalmol. 2004;242(6):468-77.

5. Nonoyama S, Shibuya Y, kodama T, Masuda H, Ohira A. Recovery of vision after chiasmal optic neuritis. Acta Ophthalmol Scand. 2003;81(1):83-4.

6. O'Riordan JI, Gallagher HL, Thompson AJ, Howard RS, Kingsley DP, Thompson EJ, et al. Clinical, CSF, and MRI findings in Devic's neuromyelitis optica. J Neurol Neurosurg Psychiatry. 1996;60(4):382-7.

7. Papais-Alvarenga RM, Miranda-Santos CM, Puccioni-Sohler M, de Almeida AM, Oliveira S, Basílio de Oliveira CA, et al. Optic neuromyelitis syndrome in Brazilian patients. J Neurol Neurosurg Psychiatry. 2002;73(4):429-35.

8. Piccolo G, Franciotta DM, Camana C, Bergamaschi B, Banfi P, Sandrini G, Citterio A. Devic's neuromyelitis optica: long-term follow-up and serial CSF findings in two cases. J Neurol. 1990;237(4):262-4.

9. O'Riordan JI, Walker M, Plant GT, Grahahm EM. Non-communicating syringomyelia and neuromyelitis optica. J Neurol. 1999;246(4):314-6.

10. Bergamaschi R, Ghezzi A. Devic's neuromyelitis optica: clinical features and prognostic factors. Neurol Sci. 2004;25 Suppl 4: S364-7.

11. Burde RM, Savino PJ, Trobe JD. Clinical decisions in neuro-ophthalmology. 3rd ed. St.Louis: Mosby; 2002. p.62.

12. Keltner JL, Johnson CA, Spurr JO, Beck RW. Visual field profile of optic neuritis. One-year follow-up in the Optic Neuritis Treatment Trial. Arch Ophthalmol. 1994;112(7):946-53.

13. Wingerchuk DM, Hogancamp WF, O'Brien PC, Weinshenker BG. The clinical course of neuromyelitis optica (Devic's syndrome). Neurology. 1999; 53(5):1107-14.

14. Newman NJ, Lessell S, Winterkorn JM. Optic chiasmal neuritis. Neurology. 1991;41(8):1203-10. Review. 